\title{
Integrating visitor characteristics and preferences into forest management plans in protected areas: A case study in Köprülü Canyon National Park
}

\author{
Uzay Karahalil, Emin Zeki Başkent \& Selahattin Köse
}

Keywords: visitor profile, visitor expectation, forest management plan, protected areas, Köprülü Canyon National Park

\section{Abstract}

Designing a protected area forest management plan is a challenging task given the difficulties in balancing conservation and utilization values in a sustainable manner. Köprülü Canyon National Park (NP) was selected as the target of a study of visitor perceptions and expectations as it provides many goods and services, including historical and natural resources, and is the most visited national park in Turkey. Different demographic characteristics like gender, age or nationality, visitor characteristics such as visit frequency, seasonal preferences or transportation methods, and expectations, such as the objective of the visit, regional preference and deficiencies in recreational facilities were investigated. We found that the most important park characteristic is its suitability for rafting, which $71.1 \%$ respondents reported as their preferred activity. Four forest values, including aesthetics, recreation, water conservation and nature conservation across 2735 ha $(7.6 \%$ of the total area), were determined according to the visitors' perceptions.
Profile

Protected area

Köprülü Canyon

National Park

Mountain range

Taurus mountains

Country

Turkey

\section{Introduction}

Management and planning of protected areas are necessary to balance conservation of the environment and sustainability of resource usage. Each country has developed its own protected area systems, which largely depend on social, economic and cultural requirements set out by national governing bodies. The need for protection of areas of interest was first realized in the United States with the designation of Yellowstone NP in 1872. NPs are common designations for protected areas, whereby an area of natural or semi-natural land is set aside for human recreation and enjoyment, animal and environmental protection, and is often managed for rehabilitation, improvement and persistence of ecosystems contained within (IUCN 1994; Thomas \& Middleton 2003). Generally most of NPs internationally operate under similar mandates.

Many countries recognize and actively promote the benefits of visitor access to NPs. As a result they face a difficult dilemma in balancing the dual objectives of visitor use and resource protection. Success in achieving an appropriate balance between resource use and resource protection requires professional management of a park's natural resources and visitor use. During the planning process, visitor characteristics, motivations, demands, expectations, information on visitor attitudes, preferences and perceptions should be integrated to guide management decisions in a NP (Obua \& Harding 1996; Manning 1999; Eagles \& McCool 2002).

Several studies have investigated the relationships between demographic characteristics, perceptions and preferences (Absher \& Lee 1981; Smith \& Moore 1990; Gülez 1992; Vaske et al. 1996; Demirel 1997;
Manning 1999; Priskin 2003; Fleishman et al. 2004; Daşdemir 2005; Leujak \& Ormond 2007; Verdin et al. 2008; Düzgüneş 2009; Sayan \& Karagüzel 2010). To our current knowledge no study exists on the integration of visitor characteristics or preferences into forest management plans in protected areas at the national and international level.

Ideally every NP should have a general management plan (GMP) that guides all developments within the park and outlines the objectives. The GMP contains guiding principles for core park protection, buffer and utilization zones, and guidelines within these areas. To achieve the desired targets, implementation plans are needed to prepare the tactical or operational level activities, such as fire management, grazing or protection plans in accordance with the GMP for NPs (Thomas \& Middleton 2003). One of these plans is a forest management plan (FMP), designed foremost to provide health and sustainability of forest ecosystems, serving goods and services to the public in NPs (Köse et al. 2005; Karahalil 2009). A FMP should be prepared when an intervention is deemed necessary to maintain forest ecosystem sustainability, improvement or rehabilitation, and is seen as complementary to the park management plan. Additionally, FMPs are seen as subordinate plans coherent with the national park GMP.

The absence of both GMP and FMP jeopardizes strategic level policies to protect natural and historical values, to maintain the distinctive characteristics of the park, to provide opportunities for recreation within the park and to provide an adequate range of goods, services and facilities for local people and visitors. Determination of visitor demographics, perceptions and expectations is particularly important during the 


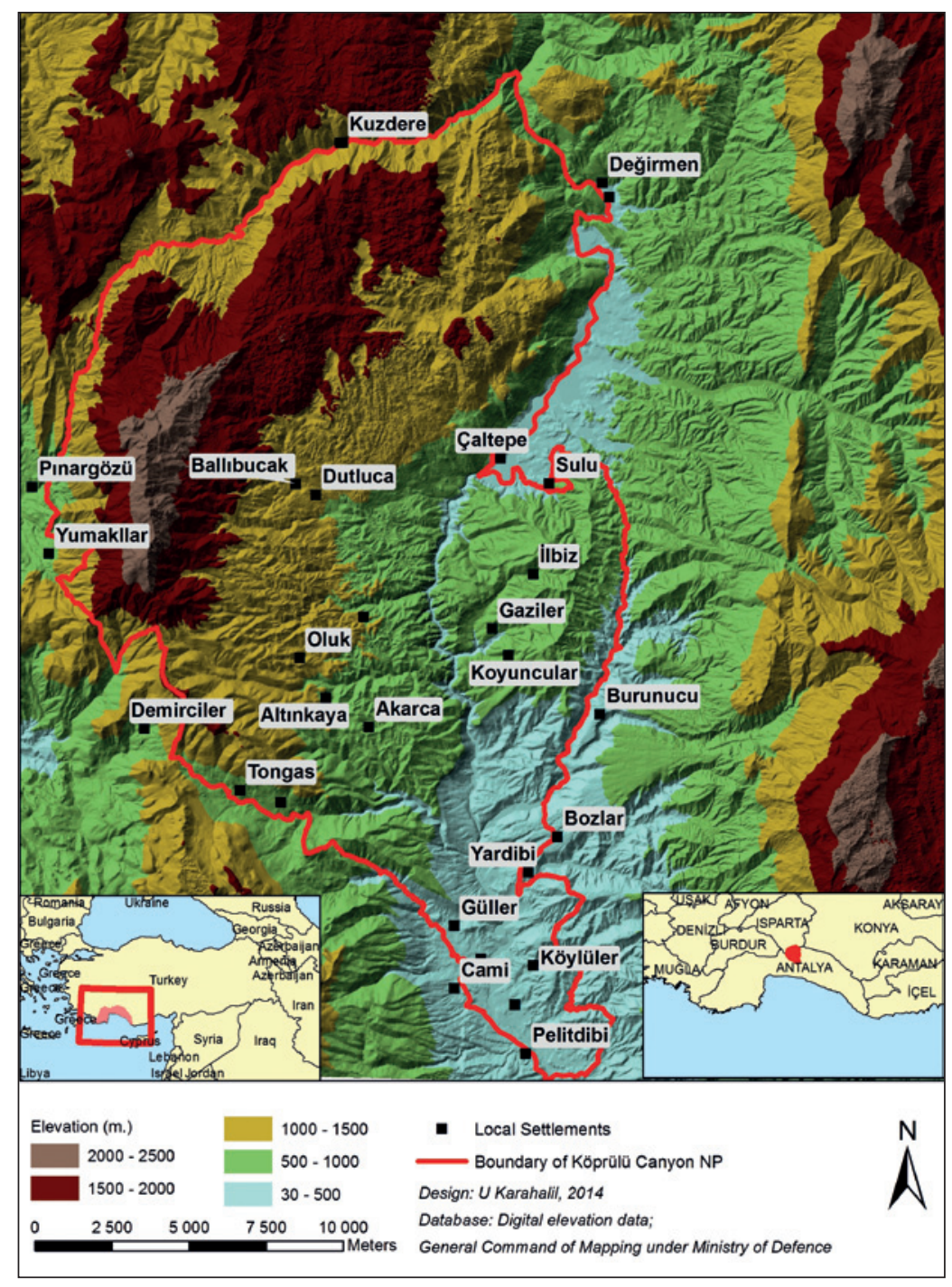

Figure 1 - Location of Köprülü Canyon NP

planning process. An effective FMP can be prepared to sustain a balance between public needs and nature conservation. However, for Köprülü Canyon NP, data on socio-economic features of the user population, visitor characteristics, preferences, views and expectations have not been adequately gathered and analysed to formulate such a plan. The observed conflicts between visitors and nature conservation relate to the uncontrolled ecotourism and recreation activities in this NP. There is a great visitor demand, especially for rafting. However, at this point it has not been clarified in the GMP which areas should be allocated to protecting water resources. Such uncertainties create conflicts between visitors and nature conservation. In the meantime, there is a conflict between the local people and nature conservation. The local people are sceptical about allocating the land to various uses. They expect that in future any commercial uses of the NP would exclude the local people.

Sophisticated socio-economic data can provide a better understanding of outdoor recreation and help to analyse the problems and issues faced in the process of developing the FMP. For example, it is relevant to know which recreational activities or natural features have influenced visitors. Could these attractions be increased or moved to other regions of the NP? Does the NP have a characteristic visitor profile? Which parts of the NP are used by the visitors? In other words, what places will be allocated to recreational uses? To integrate these issues in the park planning process, a study was carried out in Köprülü Canyon NP, Turkey. Köprülü Canyon NP was selected for this study because of the significance of its cultural and natural resources and its international visitor profile.

\section{Material and Methods}

\section{Study Area}

The area selected for study, Köprülü Canyon NP, is located in the southern Mediterranean region of Turkey, between the towns of Antalya and Isparta, (324500-343000 E and 4143000-4110000 N, UTM ED 50 datum Zone $36 \mathrm{~N})$. It is one of 40 national parks in Turkey (GDNP 2014). Köprülü Canyon NP is characterized by steep and rough terrain and stretches across a total area of 35452.8 ha. The average gradient 


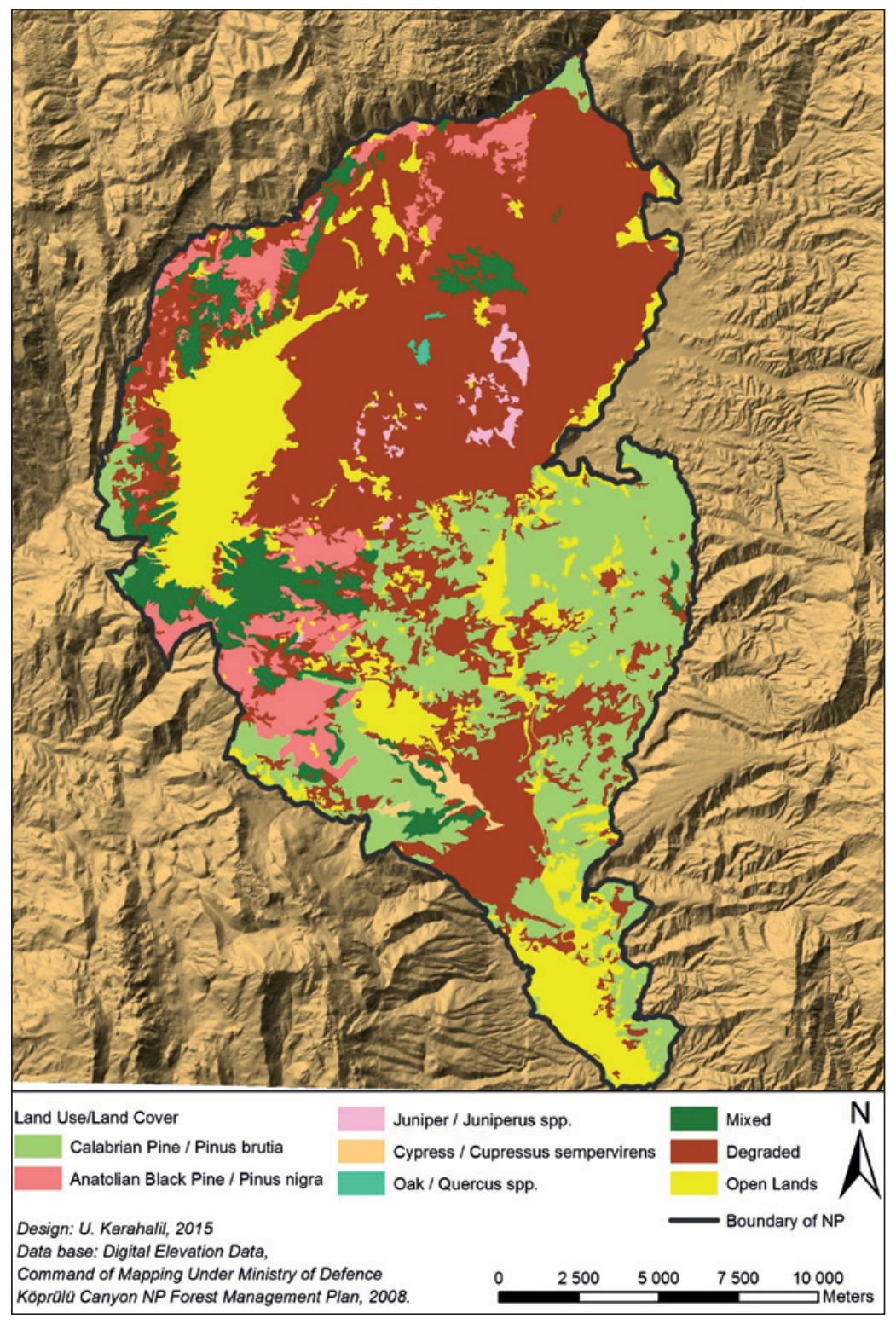

Figure 2 - Land use / land cover map of Köprülü Canyon NP

is $55.7 \%$ and altitudes range from $200 \mathrm{~m}$ to $2500 \mathrm{~m}$ above sea level (Karahalil 2009) (Figure 1).

The park has remarkable landscape features, such as the typical forest stands of the Mediterranean region, habitats for wildlife, valuable cultural sites, interesting geomorphic phenomena, the springs of the Köprüçay River, habitats of wild goats, (Capra aegagrus) and water fauna. The nearly 600 ha of pure and mixed cypress forest is a unique vegetation habitat in the world (GDNP 2008) (Figure 2). Forest lands in the NP are state-owned and there is no private forest owner. The area also includes Köprüçay creek, which has ecotourism potential for rafting and canoeing activities in the downstream section, starting from the ancient Oluk Bridge and finishing below the village of Beşkonak (Figure 3).

The NP includes the notable ancient city of Selge (established $\sim 5 \mathrm{BC}$ ), with its theatre and bazaar. The park is exceptional in terms of vegetation cover, historical features, aesthetics, eco-tourism and cultural aspects. Köprülü Canyon NP is also important as a recreational resource for the residents of Antalya, (located $88 \mathrm{~km}$ from the park), a dense urban centre, which receives a large influx of tourists, particularly in the summer. Although the GMP of Köprülü Canyon NP has not been completed yet, a draft plan was prepared to identify three zones (core, buffer and transition) and corridors / pathways. One of the main principles for establishing the buffer zone is to provide a rational use of natural resources and ecotourism potential, e. g. on-going rafting activities. The archaeological monuments located along the Köprülü River were also considered in the proposed buffer zone for their cultural value and tourism potential. It also envisages the buffer zone to be used for cooperative activities compatible with sound ecological practices, including environmental awareness, recreation, ecotourism, applied/basic research and seasonal use of natural resources. According to the draft GMP the target of the buffer zone includes regulating the uncontrolled rafting 
Table 1 - Questions and choices applied to visitors

\begin{tabular}{|c|c|}
\hline Questions & Choices \\
\hline \multicolumn{2}{|l|}{ Socio-demographic } \\
\hline Gender & Female, male \\
\hline Age & $16-25,26-35,36-45,46-55,56-65$, more than 65 \\
\hline Academic background & Elementary, secondary, high school, university, graduate, illiterate \\
\hline Occupation & Student, officer, worker, retired, self-employment, farmer/villager, housewife, other \\
\hline Monthly family income & Low, moderate, high, very high \\
\hline Visitor type & Domestic tourist, day tripper/recreationist, international tourist, other \\
\hline \multicolumn{2}{|l|}{ Visitor preference } \\
\hline $\begin{array}{l}\text { Which season you prefer to come } \\
\text { to the park }\end{array}$ & January, February, Mach, April, May, June, July, August, September, October, November, December \\
\hline Frequency of visit & $\begin{array}{l}\text { Two or more in a week, all weekend, once in two weeks, once a month, once in three months, once a } \\
\text { year or less, this is the first time }\end{array}$ \\
\hline Time spent in the park & 1-2 hour, 3-4 hour, 5-6 hour, half day, 1 day, more \\
\hline Type of transportation to the park & Tour organization, my car, bus/minibus, scientific/official organization, other \\
\hline $\begin{array}{l}\text { Distance between the park and } \\
\text { your holiday destination }\end{array}$ & Less than $10 \mathrm{~km}, 10-30 \mathrm{~km}, 30-50 \mathrm{~km}, 50-100 \mathrm{~km}, 100-200 \mathrm{~km}, 200-500 \mathrm{~km}$, more than $500 \mathrm{~km}$ \\
\hline Objective for coming to the park & $\begin{array}{l}\text { Nature walking/resting/outdoor recreation, water sports like rafting/canoeing/angling, watching the } \\
\text { environment/scenic beauty, benefiting from fishery products, recognizing/observing traditional and } \\
\text { ethnographic values, nature walking/observation, escaping from city, accommodation-hotel/pension, } \\
\text { work travelling/scientific research, sport, taking photographs, camping, mountain climbing, other }\end{array}$ \\
\hline Characteristic of this area & $\begin{array}{l}\text { Existence of forested lands, suitable for excursions, good scenery, quiet and calm, providing rafting, } \\
\text { ease of access, clean air, other }\end{array}$ \\
\hline Region preference in the park & $\begin{array}{l}\text { Rafting centre area, Bozburun mountain, canyon, antique city of Selge, near Ballıbucak with chimney } \\
\text { rocks, fish restaurants, suitable picnic areas near the roads, other }\end{array}$ \\
\hline Accommodation preference & $\begin{array}{l}\text { I don't stay overnight, hotel/pension, official guest house, local possibilities surroundings, tent camp, } \\
\text { living this region or near relatives, other }\end{array}$ \\
\hline $\begin{array}{l}\text { Deficient or inadequate recrea- } \\
\text { tional facilities }\end{array}$ & $\begin{array}{l}\text { Picnic areas, scenery viewing platforms, outdoor concert areas, children playing fields, restaurants, } \\
\text { organized camping sites, outdoor entertainment areas, walking paths, outdoor cafés, accommodation } \\
\text { for travellers, mountain or hill climbing activity areas, handicrafts and souvenir stores related to parks, } \\
\text { outdoor sport areas, helicopter tours, cable railway/teleferic, park newspaper or magazine, other }\end{array}$ \\
\hline $\begin{array}{l}\text { If there were an entrance fee, how } \\
\text { much would you be willing to pay }\end{array}$ & $1,5,10,15,20,30$ Eur, more \\
\hline \multicolumn{2}{|c|}{ Contribution of respondents } \\
\hline \multicolumn{2}{|c|}{ Open-ended question to elicit a variety of complaints about the site and their experience as well as suggestions } \\
\hline
\end{tabular}

activities, developing ecotourism areas, conserving the sensitive areas of geomorphology and hydrology along the Köprülü River with natural, landscape and cultural value. While the mechanisms to achieve these objectives were not clearly set, such mechanisms could be handled via action plans according to the national park law. For the above reasons, a FMP should be developed for Köprülü Canyon NP in response to the increasing outdoor recreational demands of an urbanized society.

\section{Data}

Various studies suggest that there are different methods to include visitor characteristics (Dravniks \& Pitcher 1982; Smith \& Moore 1990; Grocott 1990; Gülez 1992) in designing the environment. As participation is a key component in determining forest values, management goals and conservation targets leading to alternative management strategies, questionnaires are used as one method to achieve participation and involve key stakeholders. Questionnaires are effective tools to learn the characteristics and opinions of visitors. To achieve the research objectives of this study, a questionnaire form was prepared and applied to visitors.

To make sure that the survey results are representative, it is vital to have a large number of randomly se- lected participants. We used (Eq. 1) for a 95\% confidence level, meaning that there is only a $5 \%$ chance of our sample results differing from the true population average (Chapman \& Meyer 1949; Krejcie \& Morgan 1970; Laar \& Akça 2007):

$$
n=\frac{N * t^{2} * p * q}{N * m^{2}+t^{2} * p * q}
$$

where $\mathrm{n}=$ community size, $\mathrm{t}=$ confidence coefficient, $\mathrm{m}=$ error percentage, $\mathrm{p}, \mathrm{q}=$ probabilities of engaging and not engaging in activities.

Visitors come to the park every month of the year, however, July and August are the peak season. Visits in these two months account for about $70 \%$ of total annual visits to Köprülü Canyon NP. Thus there is an intensive use of the park over the summer months. Although visitor records are not regularly kept, it is estimated that nearly 360000 people visit the NP each year, while in the peak season upwards of 8000 people visit the park per day. When the number of visitors cannot be estimated, the population of the nearby city can be used to predict the potential number of visitors (Çıng1 1994; Demirel 1997; Diktaş 2006; Düzgüneş 2009; Karahalil 2009). 
Table 2 - Socio-demographic characteristics of the respondents

\begin{tabular}{|c|c|}
\hline Question & (\%) \\
\hline \multicolumn{2}{|l|}{ Gender } \\
\hline Female & 37.4 \\
\hline Male & 62.6 \\
\hline \multicolumn{2}{|l|}{ Age group } \\
\hline $16-25$ & 22.1 \\
\hline $26-35$ & 31.4 \\
\hline $36-45$ & 30.2 \\
\hline $46-55$ & 12.2 \\
\hline $56-65$ & 4.1 \\
\hline More than 65 & - \\
\hline \multicolumn{2}{|l|}{ Occupation } \\
\hline Student & 8.8 \\
\hline Officer & 25.7 \\
\hline Worker & 23.4 \\
\hline Retired & 4.1 \\
\hline Self-employed & 21.6 \\
\hline Farmer/villager & 4.1 \\
\hline Housewife & 6.4 \\
\hline Other & 5.8 \\
\hline \multicolumn{2}{|c|}{ Academic background } \\
\hline Elementary & 17.4 \\
\hline Secondary & 7.0 \\
\hline High-school & 25.6 \\
\hline University & 44.8 \\
\hline Graduate & 5.2 \\
\hline Illiterate & - \\
\hline \multicolumn{2}{|c|}{ Monthly family income } \\
\hline Low & 9.3 \\
\hline Moderate & 60.5 \\
\hline High & 19.8 \\
\hline Very high & 1.2 \\
\hline Don't want to answer & 9.3 \\
\hline \multicolumn{2}{|l|}{ Type } \\
\hline Domestic tourist & 18.4 \\
\hline Recreationist & 34.5 \\
\hline International tourist & 47.1 \\
\hline Other & - \\
\hline
\end{tabular}

For (Eq. 1), N1= 360000 (according to park authorities, our observations and interviews with travel agencies), N2 $=1789000$ (population of Antalya province), $\mathrm{t}=2(\mathrm{a}=0.05), \mathrm{m}=10 \%, \mathrm{p}=0.5$, and $\mathrm{q}=0.5 \mathrm{n} 1$ and $\mathrm{n} 2$ are calculated as 99.97 and 99.99 respectively, resulting in an $\mathrm{n}(1,2)$ of 100 visitors. This means that, to have $\pm 5 \%$ margin error, a questionnaire should be applied to a sample of at least 100 visitors, based on the total average of annual visitors.

In order to minimize the effect of missing data, the questionnaire was administered to 172 randomly selected volunteer respondents and of these, 166 properly completed the questionnaire without missing data or errors. Therefore 166 questionnaires were used in this study which is above the target minimum sample size of 100 . To achieve the research objectives, a questionnaire was prepared and used in interviews with different groups visiting Köprülü Canyon NP in July, August, and September. Visitor groups were selected using a random sampling technique. Because of the

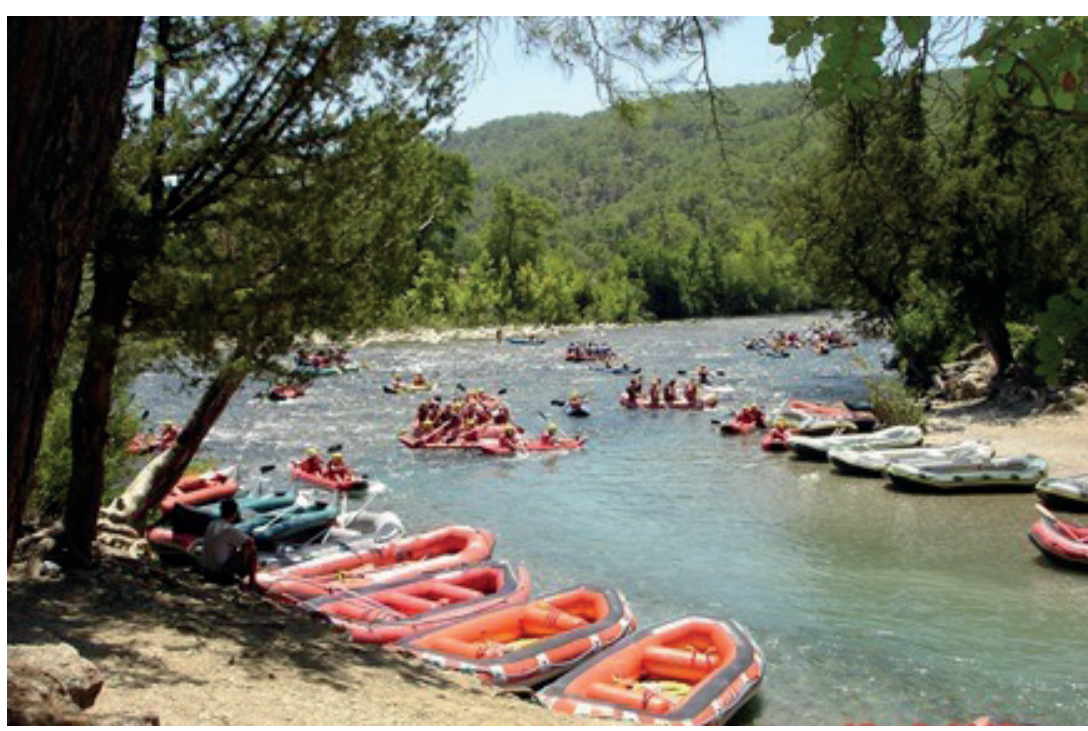

Figure 3 - Rafting in Köprülü Canyon NP

visit-oriented nature of the study, exploring experiences and perceptions was only meaningful after the visit had taken place. The questionnaires were administered by face-to-face interview with visitors after their visit, on their return to the car park or after rafting.

The template questionnaire form was prepared in three languages: English, Russian and Turkish. Respondents were asked 17 closed questions and 1 openended question, which included their profile, perceptions, preferences and opinions. Visitors would mark more than one choice for the questions $7,12,13,14$, and 16. Questions were classified under the given topics (Table 1).

Evaluation of data and method of approach

Frequencies of each category and relationships between socio-demographic and visitor preferences were calculated. The association between each sociodemographic characteristic and visitor preference was investigated using chi-square tests after grouping some of the questions together. The Statistical Package for Social Science (SPSS) Version 13.0 and Excel 2010 were used for the analyses.

The idea of NPs has expanded throughout Turkey and the world and these areas are recognized for their natural, historical and recreational value. Synchronizing the balance between conservation and recreational use is a challenging task and must be pursued on a sustainable basis. Any forest management actions or regulations will change the status of forest ecosystems in the park, including forest biodiversity. Thus, designing appropriate management actions (i.e., silvicultural prescriptions) to protect and monitor biodiversity is crucial.

A new approach to develop a FMP based Ecosystem-Based Multiple Use (ETÇAP) is a promising move towards protecting the sustainability of NP ecosystems. The new planning approach focuses on the maintenance of a NP's biodiversity, productiv- 


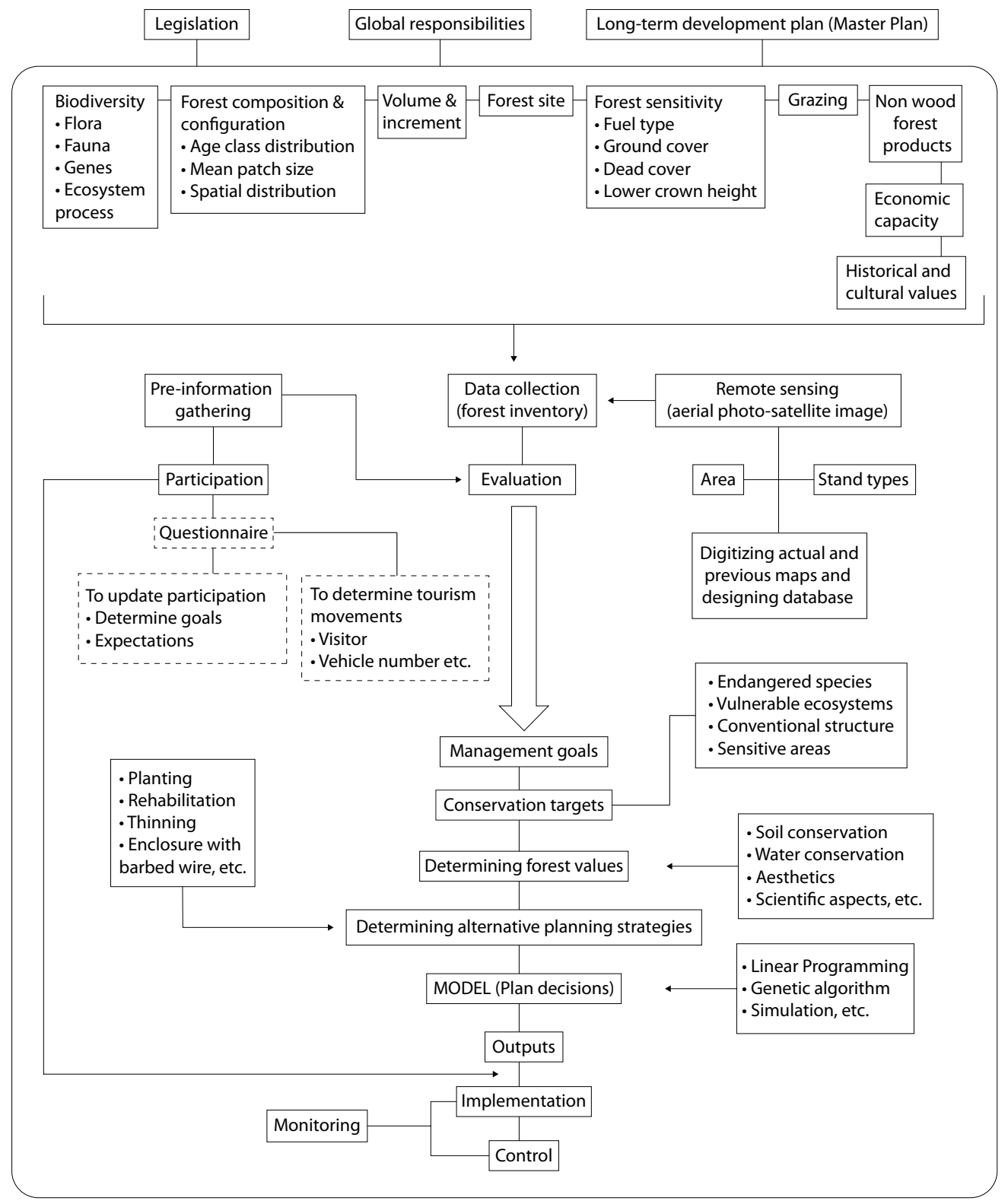

Figure 4-Conceptual framework of a NP forest management plan

ity, regeneration capacity, vitality and its potential to satisfy ecological, economic and socio-cultural values without jeopardizing the long-term sustainability of the area (Başkent et al. 2008a; Başkent et al. 2008b). A conceptual framework for a NP management plan is developed by Karahalil (2009), based on Başkent et al. (2008a, 2008b) indicated in Figure 4.

\section{Results and discussion}

Visitor profile and characteristics

Of the 166 visitors who participated in the questionnaire survey, $62.6 \%$ were male and $37.4 \%$ were female. Respondents in the age group 26-35 years constituted the largest category, followed by 36-45 year old visitors (Table 2).

Most of the visitors are public officers (25.7\%), followed by $23.4 \%$ workers and $21.6 \%$ self-employed.
These results indicate that visitors are generally working in a business. The educational level of the respondents is high, with $50.0 \%$ having a university or higher degree with a moderate income level (60.5\%). Most of the visitors are from foreign countries $(47.1 \%)$, followed by recreationists (34.5\%) coming from Antalya province. Domestic tourists are about $18.4 \%$, coming from other cities in Turkey and spending their holiday in Antalya. The perceptions and preferences of the visitors are diverse. About $52.1 \%$ of visitors come to the park in July, although $24.0 \%$ of the visitors marked July with August (Figure 5).

Most of the visitors came to the park for the first time $(44.0 \%)$, followed by $27.1 \%$ who visit once per year or less, while the proportion of all weekend visits is $4.2 \%$. About $33.5 \%$ of the visitors spent all the day in the park, followed by $20.7 \%$ who spent half a day. $18.3 \%$ of the visitors spent 5 to 6 hours in the park, 
Table 3 - Results of calculated relationships between visitor type and other visitor characteristics using chi-square tests. * = significant values

\begin{tabular}{|c|c|c|c|c|c|}
\hline \multirow{2}{*}{ Visitor characteristics and perceptions } & \multicolumn{3}{|c|}{ Visitor type (\%) } & \multirow{2}{*}{ Chi-square } & \multirow{2}{*}{ P value } \\
\hline & Domestic tourist & Recreationist & International tourist & & \\
\hline \multicolumn{6}{|l|}{ Objective for coming to the park } \\
\hline Nature walking, resting, picknicking & 36.7 & 60.3 & 30.1 & 12.735 & $0.002^{*}$ \\
\hline Water sports & 63.3 & 39.7 & 69.9 & 54.596 & $<0.001^{*}$ \\
\hline Chi-square & 2.133 & 2.483 & 11.521 & & \\
\hline$P$ value & 0.144 & 0.115 & $0.001^{*}$ & & \\
\hline \multicolumn{6}{|l|}{ Age } \\
\hline $16-25$ & 10.0 & 20.7 & 29.5 & 15.842 & $<0.001^{*}$ \\
\hline $26-35$ & 53.3 & 32.8 & 19.2 & 0.520 & 0.771 \\
\hline $36-45$ & 6.7 & 25.9 & 42.3 & 52.451 & $<0.001^{*}$ \\
\hline $46-55$ & 26.7 & 13.8 & 6.4 & 0.857 & 0.651 \\
\hline $56-65$ & 3.3 & 6.9 & 2.6 & 2.000 & 0.368 \\
\hline Chi-square & 25.667 & 11.828 & 42.000 & & \\
\hline$P$ value & $<0.001^{*}$ & $0.019^{*}$ & $<0.001^{*}$ & & \\
\hline \multicolumn{6}{|l|}{ Monthly family income } \\
\hline Low & 7.1 & 14.8 & 8.5 & 3.500 & 0.174 \\
\hline Moderate & 75.0 & 77.8 & 53.5 & 41.137 & $<0.001^{*}$ \\
\hline High & 17.9 & 7.4 & 35.2 & 24.765 & $<0.001^{*}$ \\
\hline Very high & - & - & 2.8 & 0.000 & 1.000 \\
\hline Chi-square & 22.357 & 48.444 & 47.817 & & \\
\hline P value & $<0.001^{*}$ & $<0.001^{*}$ & $<0.001^{*}$ & & \\
\hline \multicolumn{6}{|l|}{ Frequency of visit } \\
\hline Two or more in a week & - & 1.7 & 5.4 & 1.800 & 0.180 \\
\hline All weekend & 3.3 & 6.9 & 2.7 & 2.000 & 0.368 \\
\hline Once in two weeks & - & 3.4 & 1.4 & 0.500 & 0.779 \\
\hline Once a month & - & 6.9 & 1.4 & 1.800 & 0.180 \\
\hline Once in three months & 3.3 & 5.2 & - & 1.000 & 0.317 \\
\hline Once a year or less & 26.7 & 27.6 & 27.0 & 5.091 & 0.078 \\
\hline This is the first time & 53.3 & 19.0 & 59.5 & 26.732 & $<0.001^{*}$ \\
\hline Other & 13.3 & 29.3 & 2.7 & 17.304 & $<0.001^{*}$ \\
\hline Chi-square & 26.333 & 40.207 & 149.432 & & \\
\hline$P$ value & $<0.001^{*}$ & $<0.001^{*}$ & $<0.001^{*}$ & & \\
\hline \multicolumn{6}{|l|}{ Transportation method } \\
\hline Tour organization & 10.0 & 3.5 & 48.6 & 54.780 & $<0.001^{*}$ \\
\hline My car & 80.0 & 87.7 & 32.4 & 48.596 & $<0.001^{*}$ \\
\hline Bus/minibus & 3.3 & 5.3 & 13.5 & 9.571 & $0.008^{*}$ \\
\hline Other & 6.7 & 3.5 & 5.4 & 1.000 & 0.607 \\
\hline Chi-square & 48.667 & 119.632 & 33.459 & & \\
\hline $\mathrm{P}$ value & $<0.001^{*}$ & $<0.001^{*}$ & $<0.001^{*}$ & & \\
\hline \multicolumn{6}{|l|}{ Time spent in the park } \\
\hline $1-2$ hours & - & - & 11.1 & 0.0 & 1.000 \\
\hline $3-4$ hours & 20.0 & 6.9 & 19.4 & 7.000 & $0.030^{*}$ \\
\hline 5-6 hours & 16.7 & 27.6 & 13.9 & 5.871 & 0.053 \\
\hline Half day & 33.3 & 17.2 & 18.1 & 0.545 & 0.761 \\
\hline 1 day & 30.0 & 44.8 & 25.0 & 26.148 & $<0.001^{*}$ \\
\hline More day & - & 1.7 & 12.5 & 6.4 & $0.011^{*}$ \\
\hline Other & - & 1.7 & - & 0.0 & 1.000 \\
\hline Chi-square & 2.267 & 50.621 & 5.833 & & \\
\hline P value & 0.519 & $<0.001^{*}$ & 0.323 & & \\
\hline
\end{tabular}

whereas $15.2 \%$ spent 3 to 4 hours. Nearly $6.1 \%$ of the visitors stay in the park for more than one day. The owned or rented car is the most common transportation method to get to the park $(60.6 \%)$, followed by organized tours $(26.1 \%)$. About $8.5 \%$ of the visitors come to the park by bus or minibus. Most of the visitors come from $50-100 \mathrm{~km}$ away (50.3\%), while only $20.2 \%$ of the visitors come from $30-50 \mathrm{~km}$ away.
About $10.4 \%$ of visitors come from distances of 100 $200 \mathrm{~km}$ away. Nearly $65.7 \%$ of visitors chose nature walking, resting, and outdoor recreation and 55.5\% of them chose water sports like rafting and canoeing (more than one choice was allowed). Rafting is a prominent characteristic of the park and was selected by $71.1 \%$ of the visitors. The canyon was selected by $48.8 \%$ of the visitors as their regional preference, fol- 

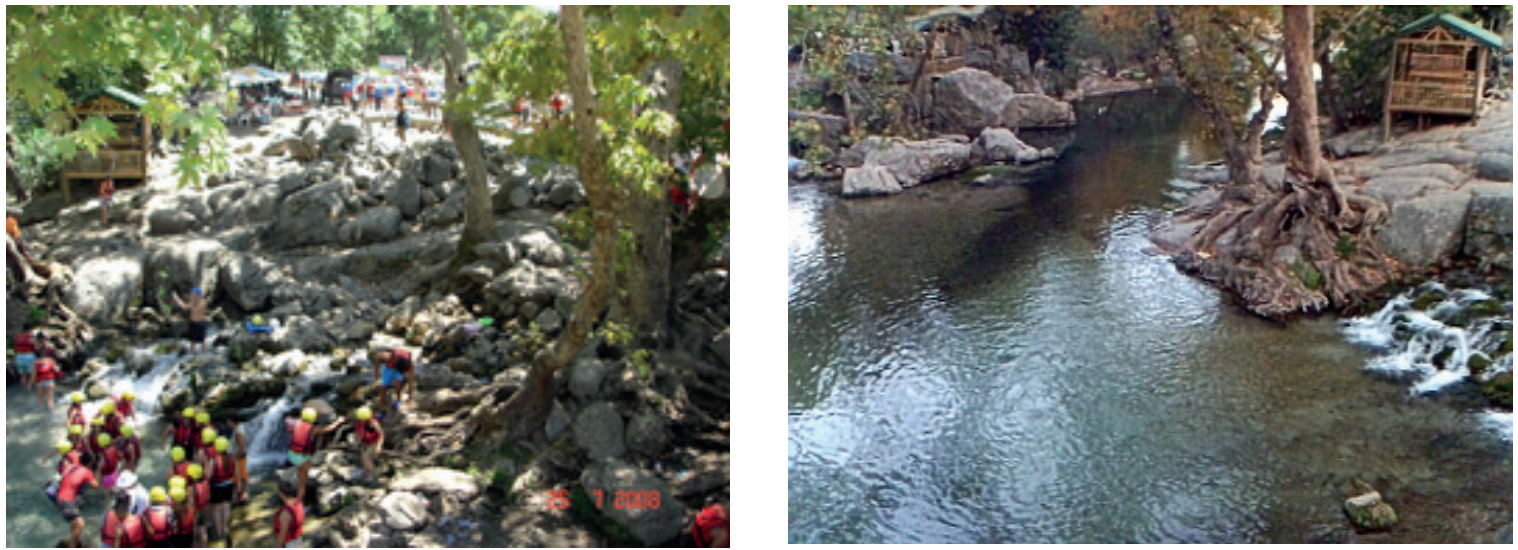

Figure 5-A stretch of river in the busiest month (July, left) and in the least visited month (December, right)

lowed by the rafting centre area $(48.2 \%)$. About $35.5 \%$ of the visitors marked another choice, the ancient Büğrüm Bridge (Figure 6).

About $78.6 \%$ of the visitors did not stay overnight in the park; only $7.5 \%$ stayed in a hotel or pension. Visitors categorized many recreational facilities in the park as deficient. They also criticized picnic areas as untidy, toilets as dirty, fountains and children's playgrounds as inadequate, walking roads as exiguous. In brief, they considered the infrastructure of the park as in poor condition. Though there is currently no fee to enter the park, $33.5 \%$ of visitors said they would pay EUR 5, while $25.2 \%$ reported they would pay EUR 10, followed by $15.5 \%$ who would pay EUR 1 . The costs for a rafting trip depend on whether it is as an individual or with a tour organization. International tourists in particular prefer tour organizations and in this case tour costs usually range between EUR 15-20, includ- ing round-trip transfers, rafting, open buffet lunch, equipment, guidance and insurance. On the other hand, visitors feel the lack of basic infrastructural services and most of them declared they would pay an entrance fee to the park to eliminate the deficiencies and to keep the environment clean.

The relationship between visitor characteristics and visitor perceptions or preferences investigated by chisquare tests, some resulting in significant associations, is presented in Table 3 and Table 4.

There are prominent associations between the reason for visiting the park (visit objective) and age group, frequency of visits and gender or education level, spending time in park and age group, transportation method to the park and monthly family income. Although gender was investigated as part of this study, no significant relationship was found between gender and visit objective.

Table 4 - Results of calculated relationships between visit objective and academic background using chi-square tests. ${ }^{*}=$ significant values

\begin{tabular}{|c|c|c|c|c|}
\hline \multirow{2}{*}{ Academic background } & \multicolumn{2}{|c|}{ Objective for coming (\%) } & \multirow{2}{*}{ Chi-square } & \multirow{2}{*}{ P value } \\
\hline & Nature walking etc. & Water sports & & \\
\hline Elementary & 28.2 & 10.6 & 3.333 & 0.068 \\
\hline Secondary school & 9.9 & 5.3 & 0.333 & 0.564 \\
\hline High school & 18.3 & 30.9 & 6.095 & $0.014^{*}$ \\
\hline University & 39.4 & 46.8 & 3.556 & 0.059 \\
\hline Graduate & 4.2 & 6.4 & 1.000 & 0.317 \\
\hline Chi-square & 28.366 & 62.277 & & \\
\hline$P$ value & $<0.001^{*}$ & $<0.001^{*}$ & & \\
\hline
\end{tabular}

Table 5 - Identified forest values and their areas in Köprülü Canyon NP.

\begin{tabular}{|l|r|l|l|}
\hline Forest value & Area (ha) & Criteria & Indicator \\
\hline Aesthetics & 2124.1 & $\begin{array}{l}\text { Topography, geological structure, stand } \\
\text { structure }\end{array}$ & $\begin{array}{l}\text { Stands seen from the most preferred road and stands includ- } \\
\text { ing the chimney rocks. }\end{array}$ \\
\hline Recreation & 5.6 & $\begin{array}{l}\text { Water sports, picnicking, camping and } \\
\text { historical areas. }\end{array}$ & $\begin{array}{l}\text { Rafting starting point, compartments containing camping and } \\
\text { picnicking areas, ancient bridges, end of the Canyon }\end{array}$ \\
\hline Water conservation & 150.9 & $\begin{array}{l}\text { Köprüçay Creek water course, reaching } \\
\text { high flow }\end{array}$ & Sub-compartments adjacent to Köprüçay Creek \\
\hline Nature conservation & 454.4 & Unique cypress stands & Pure and mixed cypress stands \\
\hline Other forest values & 32991.5 & Other forest values & $\begin{array}{l}\text { Wildlife conservation, old growth forests, non-wood forest } \\
\text { products, timber production, etc. }\end{array}$ \\
\hline Total & 35726.5 & & \\
\cline { 1 - 2 } & &
\end{tabular}


It is understood that while recreationists came for nature walking, resting and picnicking (60.3\%), domestic and international tourists came for water sports like rafting or canoeing (63.3\% and $69.9 \%)$. A large portion of international $(59.5 \%)$ and domestic tourists $(53.3 \%)$, for whom it was their first time visiting the park, reported that they are unlikely to return within the next year, while the majority of recreationists $(81.0 \%)$ have visited the park before. Nearly half of the international tourists $(48.6 \%)$ came to the park by tour organizations; however, $87.7 \%$ of the recreationists or $80.0 \%$ of the domestic tourists came with their cars. International tourists spent different amounts of time in the park, while recreationists generally spent one day $(44.8 \%)$ and domestic tourists spent half a day $(33.3 \%)$ in the park.

These findings show us that GMP and sub-plans could be reoriented on these visitor demographics and preferences. Different strategies could be developed for the three visitor types. For example, recreationists could be encouraged to try water sports. Focusing on the increasing organized tour groups could be effective for both domestic tourists and recreationists as they are for international tourists. It is clear that accommodation facilities are not preferential for all types of visitors and there is no need to allocate areas in the park for their development, even though draft GMPs envisage development areas between the village of Besskonak and the ancient Roman bridges, near the ancient city of Selge and the village of Bolasan. A new variety of activities could be developed for international tourists for increased revenues, as international tourists appear to have greater means with which to pay, as the results indicate they have higher monthly family income $(38.0 \%)$. Although these suggestions would be more useful for the GMP side, the FMP process would be affected circumstantially. For example, the reduction of development areas as suggested would lift some of the pressure on forested lands and on buffer zones around those areas which are allocated primarily for the minimization of adverse effects of park visitors and development.

\section{Integrating visitor perceptions to the FMP}

\section{Determining forest values}

Forests within the NP's provide a great variety of environmental services, including carbon sequestration, conservation of biodiversity, watershed protection and scenic beauty. Identifying and sustainably managing forest goods and values is therefore of great importance for Köprülü Canyon NP.

During the survey we encountered some interesting results. A significant portion of visitors $(71.1 \%)$ see rafting as the biggest attraction of the park, while $55.5 \%$ of visitors came for water sports like rafting or canoeing. $65.7 \%$ of respondents chose nature walking, resting, and outdoor recreation. Furthermore, we

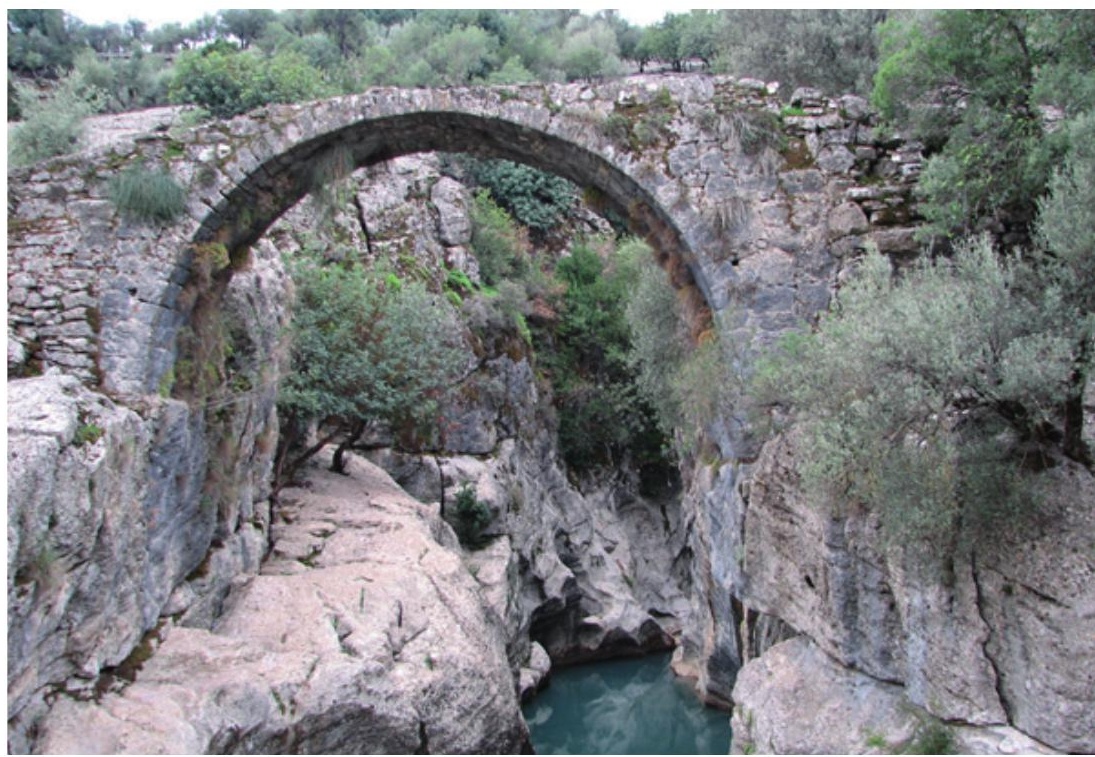

Figure 6-Bügrüm Bridge, one of two ancient bridges in the park

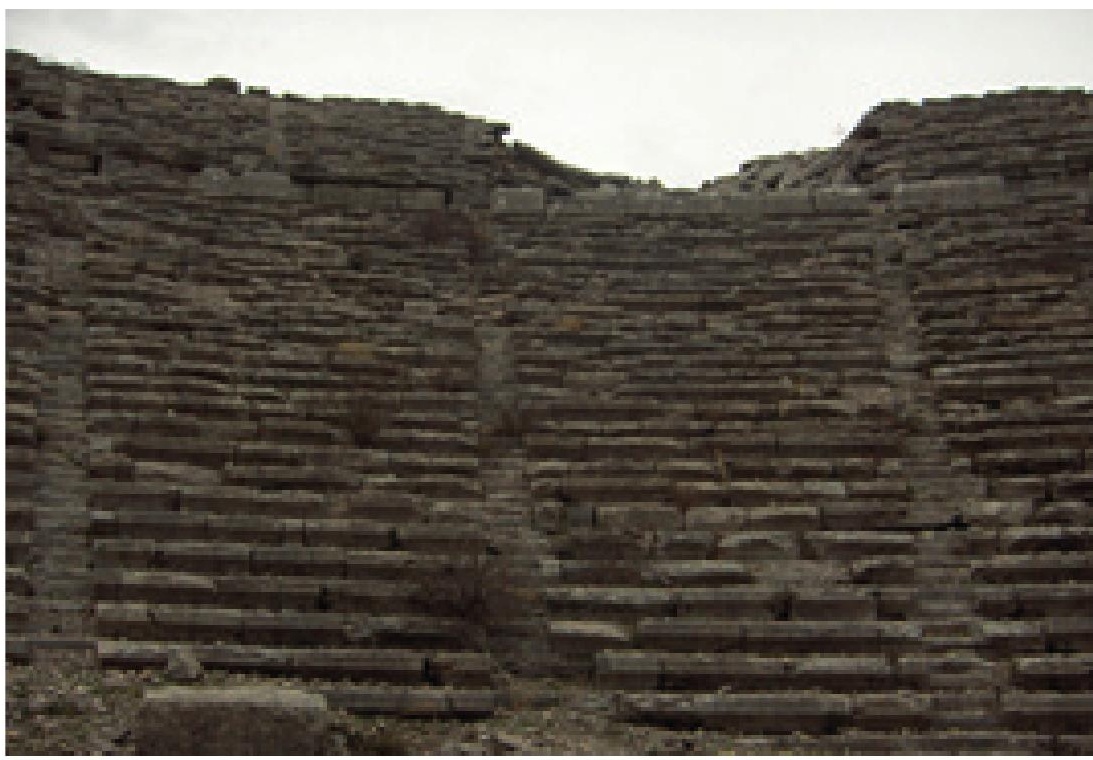

Figure 7 - Amphitheatre, ancient city of Selge

understood that nearly all of the visitors used a limited area of the NP for these activities. Rafting takes place along a $7 \mathrm{~km}$ route between the rafting centre area near the ancient Oluk Bridge and the tourism agencies region, which is approximately a three-hour trip. Nature walking, resting or picnicking stretches across almost 10 ha near two ancient bridges, Büğrüm Bridge and Oluk Bridge, at the end of the canyon.

$11.3 \%$ of visitors reportedly walk around the ancient city (Figure 7). However, more people visit the ancient city off-season, in April, May, September or November. People reach this ancient city after an adventurous bus trip of nearly $30 \mathrm{~min}$, with a view of unique cypress forests and a narrow winding road. This ancient Roman city of Selge is located on the high mountains above a dramatic gorge cut by the Köprüçay (Bridge Creek). This road is very important to visitors for its scenic views, and the adjacent for- 


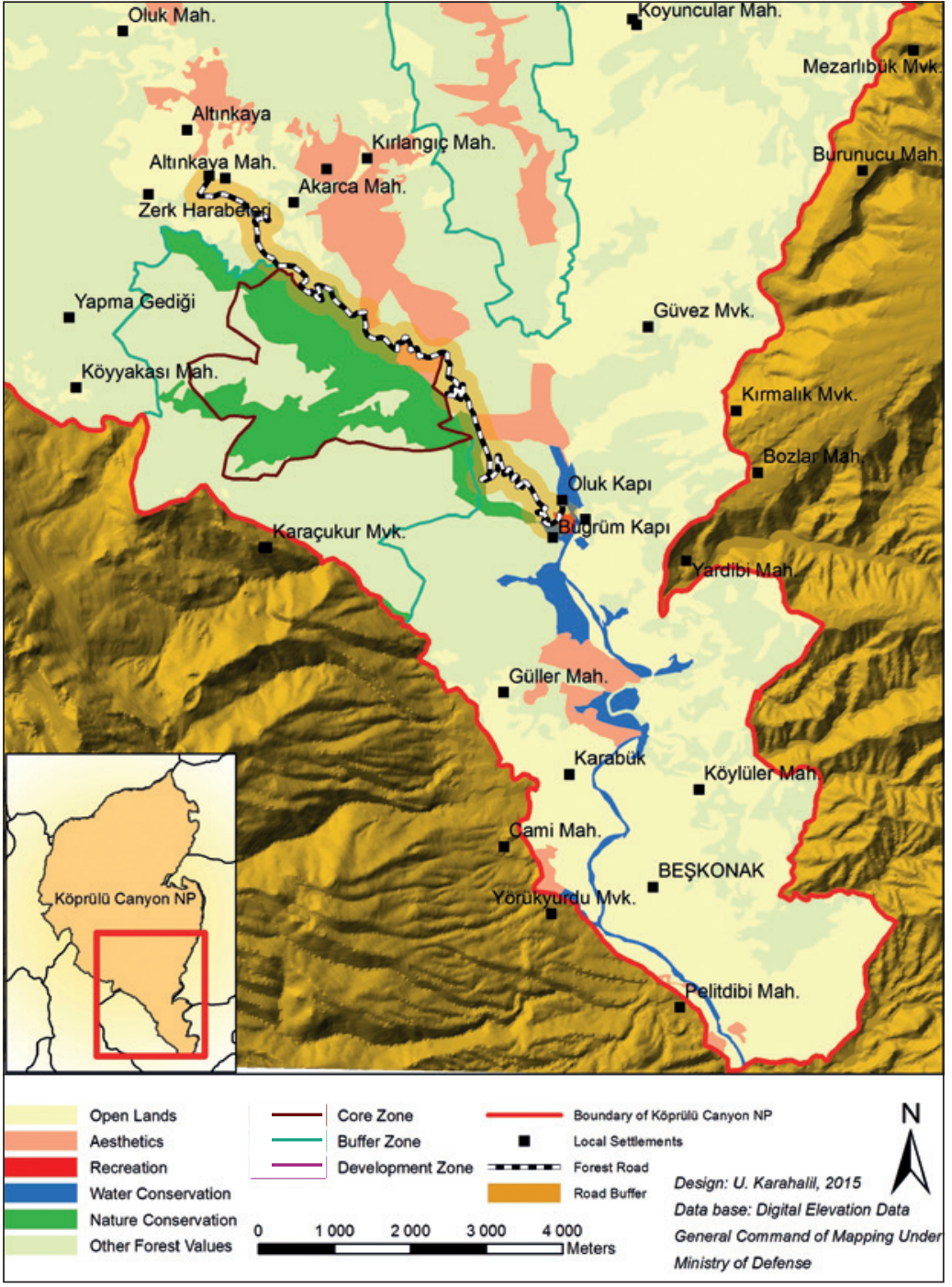

Figure 8 - Identified forest values by visitor preferences in the park.

est ecosystem should be maintained and protected by way of rehabilitation, enrichment or repair planting at the roadside. $60.6 \%$ of the visitors use their own or rented cars and stay near the roads, stopping once to take photographs of scenic views. To assist with forest protection and management objectives, a $200 \mathrm{~m}$ buffer zone could be established along the roadside, adjacent to the forest ecosystem.

In sum, visitors use and see certain parts of the NP, yet are not aware of other parts. Aesthetics, recreation, water conservation and nature conservation forest values were highlighted by the survey. These forest functions were identified as a result of interviews and in responses to questions. Other forest values, such as wildlife conservation, old growth forests, non-wood forest products, timber production forest functions, were determined by other stakeholders and were not the real focus of this survey (Figure 8).

The identified forest values and their areas according to visitor perceptions are given in Table 5 . We note that $7.6 \%$ of the total NP area $(2735 \mathrm{ha})$ is recorded as important for the visitors.

\section{Developing alternative planning strategies}

Today there is an increasing recognition of forest values other than timber production and conservation within a number of international conventions. One of the leading problems is the accommodation of other values in forest management plans while protecting the sustainability of forest ecosystems. For example, water production is one of the most critically important forest values provided by Köprülü Canyon NP. Water production stands out primarily as a demand for recreational rafting. Two years ago, water levels in the NP were so low that rafting boats began to tear, rendering the sport largely impractical. It is thus important for planners to sustain water flow over peak visitor periods in the park (Figure 9), particularly considering its primary importance to visitors of the park.

As tourist activities take place within a limited area, while conservation objectives are relevant over the entire park, a FMP for Köprülü Canyon NP can be developed to integrate water production as well as other objectives, taking different planning strategies into account. For example, FMPs could aim to maximize water production or maintain a certain percent of wa- 


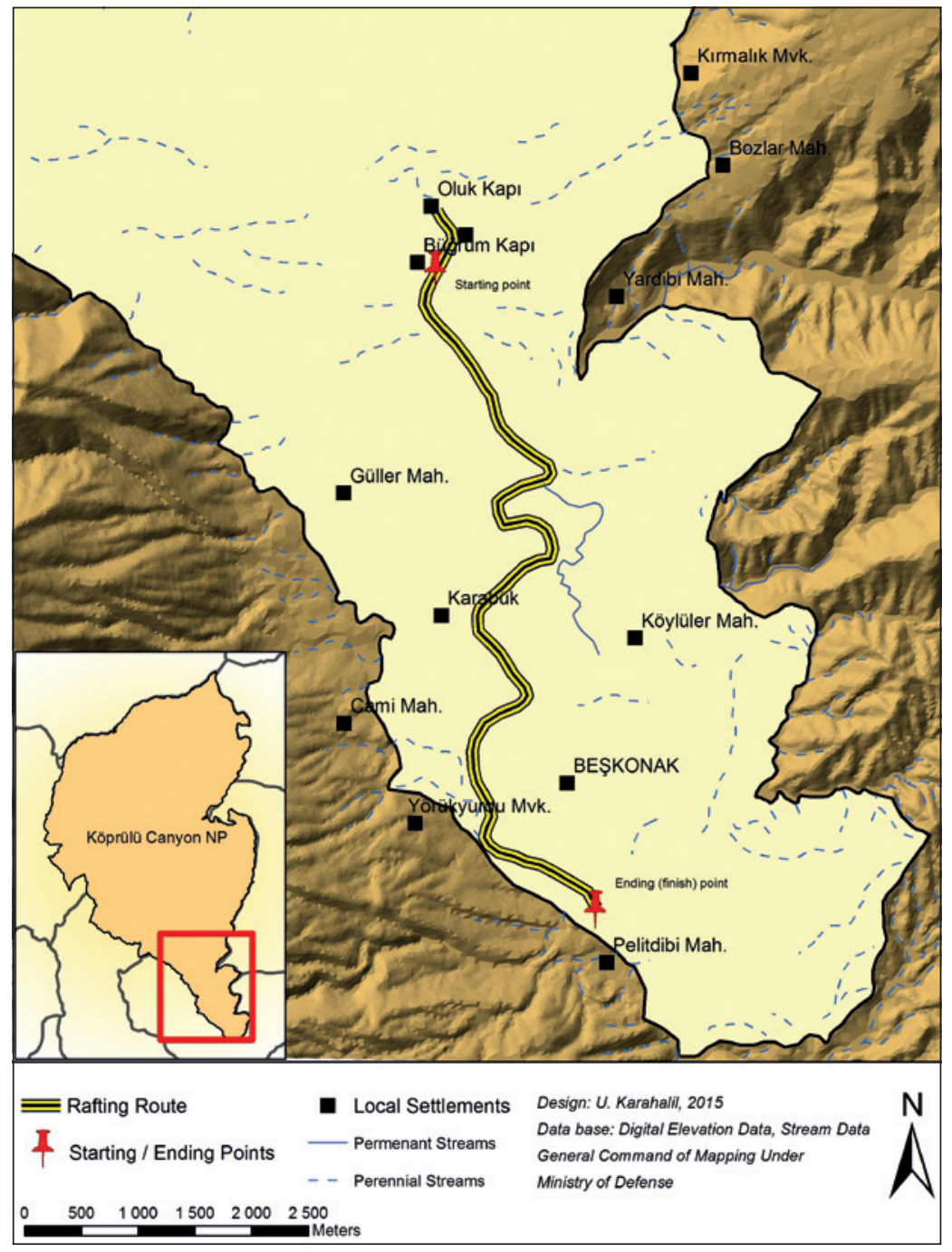

Figure 9 - Rafting route from the rafting centre area to the southern end of the park

ter flow based on stand structure and flow regression models. A number of management strategies can be developed to examine the options and opportunities and reflect the sensitivity of various constraints. In this way, contrary to conventional plans, alternative management strategies can be developed to consider many options, which can then be presented to planners and decision makers, giving managers choices in the implementation of alternatives.

\section{Conclusions and suggestions}

Turkey has remarkable forest resources with a high level of biodiversity. The country has a well-established nature preservation programme accommodating NPs since 1958. Currently it administers 40 NPs covering nearly 900000 ha and has a mandate to maintain and conserve the wealth of flora and fauna, archaeological and historical monuments, and other extraordinary features. Of the NPs, Köprülü Canyon, located in the province of Antalya in the Mediterranean region, accommodates many visitors, often upwards of 8000 people per day in the peak season. Additionally, Köprülü Canyon is home to a large number of en- demic plants and rare animal species, archaeological and historical ruins, and rich habitats. In addition to its archaeological and geological treasures, this park is also home to water-based activities, especially rafting and canoeing. Use of Köprülü Canyon NP is likely to be influenced by the outdoor recreational requirements of urbanized societies due to the park's proximity to a centre of tourism and the large city of Antalya, and the associated availability of transportation facilities. However, during the planning process for this NP, the profile and the perceptions of the visitors were not taken into consideration. Unplanned uses may degrade the forest ecosystem and endanger the sustainability of the park.

A FMP coherent with the GMP is useful for NPs. A FMP is seen as a method for conservation, enhancement, rehabilitation and sustainability of the forest ecosystem via forestry applications like planting, maintenance, thinning to reduce the effect of wild fires, or to supply local communities' timber needs while upholding conservation. The effective land allocation for various activities in the NP would be carried out based on an effective participation of main stakeholders during the preparation of planning. This study is useful 
for tactical and strategic planning and management of Köprülü Canyon NP as a means of addressing missing information and potential problems for implementing sustainable management practices. As a result of this study, park aesthetics, recreation, water and nature conservation stand out as Köprülü Canyon NP values, according to visitor questionnaire feedback. Nature walking, resting and outdoor recreation, water sports like rafting or canoeing are among the most popular activities, the last two preferred by most of the visitors $(55.3 \%)$. Rafting in particular provides the most revenue for local people. Therefore management of Köprülü Canyon NP should focus on these preferred activities, rafting, viewing the scenery, nature walking, trekking and picnicking, by broadening other parts of the NP, especially to the nearby village of Ballibucak, the place of the chimney rocks. In addition, integrated marketing decisions related to these activities should be considered in the context of planning and management of the park. Furthermore, the local people should be seen as offering a great opportunity for providing local services to the visitors. The NP authorities would recognize that fact to ease the possible conflicts between local people and nature conservation. When the above management implications are taken into consideration, Köprülü Canyon NP would be well planned and managed to balance conservation, sustainability and natural resource use. In addition to this, management design should be linked to monitoring and evaluating system as an early warning system to take measures against potential problems.

We know that park managers are often charged with a dual mission. Their first obligation is protecting natural resources for future generations. Their second responsibility is providing appropriate public enjoyment of these resources. This study guides park managers by using visitor perceptions like determining forest values and developing alternative planning strategies by means of implementing their second responsibility. On the other hand, it should always be kept in mind that the participation has limits, particularly on technical matters. Generally planners have difficulty in allocating visitor-related forest values like aesthetics or recreation in terms of size and park area for the period of the FMP process. The results of this study demonstrate that the experience of outdoor recreation in Köprülü Canyon NP is influenced by demographic characteristics and perceptions of visitors. Understanding the preferences and perceptions of visitors will better inform the development of an integrated management system that considers both resource protection and visitor experience. Visitor information and the recreational experiences need to be considered in developing and improving both the GMP and the FMP.

The methods applied and findings obtained in the study provide a basis for other similar studies on the management of protected areas. When Köprülü Canyon NP management plans consider visitor perspec- tives and perceptions, subsequent formation of park legislation, organization, ownership, protection and financial viability will be improved. In conclusion, the findings of this study will assist Köprülü Canyon NP management authority in formulating cohesive policies and aid them in better planning decisions over the often conflicting challenges of conservation and resource utilization values.

\section{Acknowledgments}

We would like to extend our thanks specifically to Mehmet Hasdoğru and his staff assigned to manage Köprülü Canyon NP. The financial support, provided by the Scientifc Research Projects Coordination Unit of Karadeniz Technical University (BAP), under project number 2006.113.001.4 is also gratefully acknowledged.

\section{References}

Absher, J.D. \& R.G. Lee 1981. Density as an incomplete course of crowding in backcountry setting. Leisure Sciences 4: 231-247.

Başkent, E.Z., Ş. Başkaya \& S. Terzioğlu 2008a. Developing and implementing participatory and ecosystem based multiple use forest management planning approach (ETÇAP): Yalnızçam case study. Ecology and Management 256: 798-807.

Başkent, E.Z., S. Terzioğlu \& Ş. Başkaya 2008b. Developing and implementing multiple use forest management planning in Turkey. Environmental Management 42: 37-48.

Chapman, H. \& W.H. Meyer 1949. Forest Mensuration. New York.

Çıng1, H. 1994. Örnekleme kuramı. Hacettepe Üniversitesi, Fen Fakültesi Yayınları, Ders Kitapları Dizisi, No:20, Ankara.

Daşdemir, İ. 2005. Improving operational planning and management of national parks in Turkey: A case study. Environmental Management 35(3): 247-257.

Demirel, Ö. 1997. Çoruh havzası (Yusufeli kesimi) doğal ve kültürel kaynak değerlerinin turizm ve rekreasyon potansiyeli açısından değerlendirilmesi üzerine bir araştırma. PhD Thesis, Karadeniz Technical University, Trabzon.

Diktaş, N. 2006. Maçka-Zigana ve Maçka Altındere Vadisi Milli Parke karayolu güzergablarnda orman kaynaklarna yönelik rekreasyonel kullanmlar. $\mathrm{PhD}$ Thesis, Karadeniz Technical University, Trabzon.

Dravniks, D. \& D.C. Pitcher 1982. Public participation in resource planning. US Department of Agriculture, Berkeley, California.

Düzgüneş, E. 2009. Altındere Vadisi Milli Parkinda (Trabzon) koruma değeri ile turizm potansiyelinin saptanmasına yönelik bir yöntem yaklaşımı. MSc Thesis, Karadeniz Technical University, Trabzon. 
Eagles, P.F.J. \& S.F. McCool 2002. Tourism in parks and protected areas: planning and management. CABI Publishing, Wallingford.

Fleishman L, E. Feitelson \& I. Salomon 2004. The role of cultural and demographic diversity in crowding perception: Evidence from nature reserves in Israel. Tourism Analyses 9: 23-40.

GDNP 2008. Draft Master Plan of Köprülü Canyon National Park, General Directorate of Nature Conservation and National Parks, Ankara.

GDNP 2014. Statistics of the year 2013. Available at: http://www.milliparklar.gov.tr/Anasayfa/istatistik. aspx?sflang=tr (accessed:25/12/14)

Grocott, A. 1990. Design our own park. Leisure Manager 8(6): 50-51.

Gülez, S. 1992. Effect of public opinion on national park planning in Turkey: A case study. Environmental Management 16(3): 355-362.

IUCN 1994. Definition of a protected area. Guidelines for protected areas management categories. CNPPA with the assistance of WCMC, IUCN (World Conservation Union), Gland.

Karahalil, U. 2009. Designing forest management plans for forested protected areas: A case study in Köprülï Canyon National Park. PhD Thesis, Trabzon.

Köse, S., U. Karahalil \& A. Günlü 2005. The importance of forest management plans in protected areas. Protected Natural Areas Symposium, Isparta.

Krejcie, R.V. \& D.W. Morgan 1970. Determining Sample Size for Research Activities. Educational and Psychological Measurement, 30: 607-610.

Laar, A. \& A. Akça 2007. Forest Mensuration. The Netherlands.

Leujak, W. \& R.F.G. Ormond 2007. Visitor perceptions and the shifting social carrying capacity of south Sinai's coral reefs. Environmental Planning 39: 472-489.

Manning, R.E. 1999. Studies in outdoor recreation: Search and research for satisfaction. Oregon State University Press, Corvallis, Oregon.

Obua, J. \& D.M. Harding 1996. Visitor characteristics and attitudes towards Kibale National Park, Uganda. Tourism Management 17(7): 495-505.

Priskin, J. 2003. Tourist perceptions of degradation caused by coastal nature-based recreation. Environmental Management 32(2): 189-204.

Sayan, S. \& O. Karagüzel 2010. Problems of outdoor recreation: The effect of visitors' demographics on the perceptions of Termessos National Park, Turkey, Environmental Management 45: 1257-1270.
Smith, N. \& S. Moore 1990. Identifying park users and their expectations: A fundamental component in management plans. Australian Parks and Recreation 26(1): 35-41.

Thomas, L. \& J. Middleton 2003. Guidelines for management planning of protected areas. IUCN Gland, Switzerland and Cambridge.

Vaske J.J., M.P. Donnely \& J.P. Petruzzi 1996. Country of origin, encounter norms and crowding in a frontcountry setting. Leisure Sciences 18: 161-176.

Verdin, G.P., M.E. Lee \& D.J. Chaves 2008. Planning forest recreation in natural protected areas of southern Durango, Mexico, Madera y Bosques. 14(1): 53-67.

\section{Authors}

\section{Uzay Karahalil'}

a specialist in designing protected area forest management plans, using remote sensing, geographic information systems and operations research in forest management applications. Currently assistant professor at Karadeniz Technical University, Faculty of Forestry.Email: uzay@ktu.edu.tr

\section{Emin Zeki Başkent ${ }^{1}$}

forest management specialist for developing forest management planning systems, building quantitative forest models, incorporating biodiversity into planning systems, using geographic information systems in forestry. Professor and dean of Karadeniz Technical University, faculty of forestry. Email: baskent@ktu.edu.tr

\section{Selahattin Köse'}

his studies focus on ecosystem-based multi-objective planning in terms of biodiversity, describing forests digitally, defining an equilibrium of sustainability of conservation and utilization according to determined goals and targets. Professor at $\mathrm{Ka}-$ radeniz Technical University, Faculty of Forestry. Email: skose@ktu.edu.tr

${ }^{1}$ Karadeniz Technical University, Faculty of Forestry, 61080, Trabzon, Turkey

(C) all pictures: Uzay Karahalil 